\title{
FEATURE Settlement, development, despoilment, and recovery of the Hudson River, New York
}

Lois Wright Morton and Kenneth R. Olson

$\mathrm{T}$ he mid-nineteenth century Hudson River School of painting reflects artists' views of American paradise, a glorified Hudson River landscape where the disappearing wilderness, agriculture, and human settlements coexisted along the river in perfect harmony. The romantic, peaceful coexistence of nature and humans became an unsustainable illusion as the twentieth century $507 \mathrm{~km}$ (315 mi) Hudson River became a major transportation route to the northern and western interior of the United States (figure 1). Like many rivers throughout history, navigation of the Hudson River waters fostered tanneries, paper mills, factories, electrical plants, and other enterprises along its coastline (Rothstein 2019). Rivers, with their abundant water supply and capacity to transport raw materials and finished goods, fueled the Industrial Revolution of the 1800s, and the Hudson River was exemplary in its contributions. Settlements and industries along the Hudson River valley flourished, creating jobs, expanding communities, and bringing economic prosperity to the region and the nation. In its wake, followed an era of industrial pollution that left an ugly mark on the river celebrated for its beauty and pristine waters. In 1984, $321 \mathrm{~km}(200 \mathrm{mi})$ of the Hudson River was classified by the US Environmental Protection Agency (USEPA) as the Hudson River PCBs Superfund site - one of the largest in the country.

The development, degradation, and recovery of the Hudson River, its river banks, and the New York City (NYC) harbor is the story of a new country taming a wilderness, the growing pains and unintended consequences of uncontrolled economic entrepreneurship, and an emerging environmental ethic. As early as

Lois Wright Morton is professor emeritus of sociology, College of Agriculture and Life Sciences, Department of Sociology, lowa State University, Ames, lowa. Kenneth R. Olson is professor emeritus of soil science in the College of Agricultural, Consumer, and Environmental Sciences, Natural Resources and Environmental Sciences, University of Illinois, Urbana, Illinois.

\section{Figure 1}

The Hudson and Mohawk River basin in the State of New York, United States.

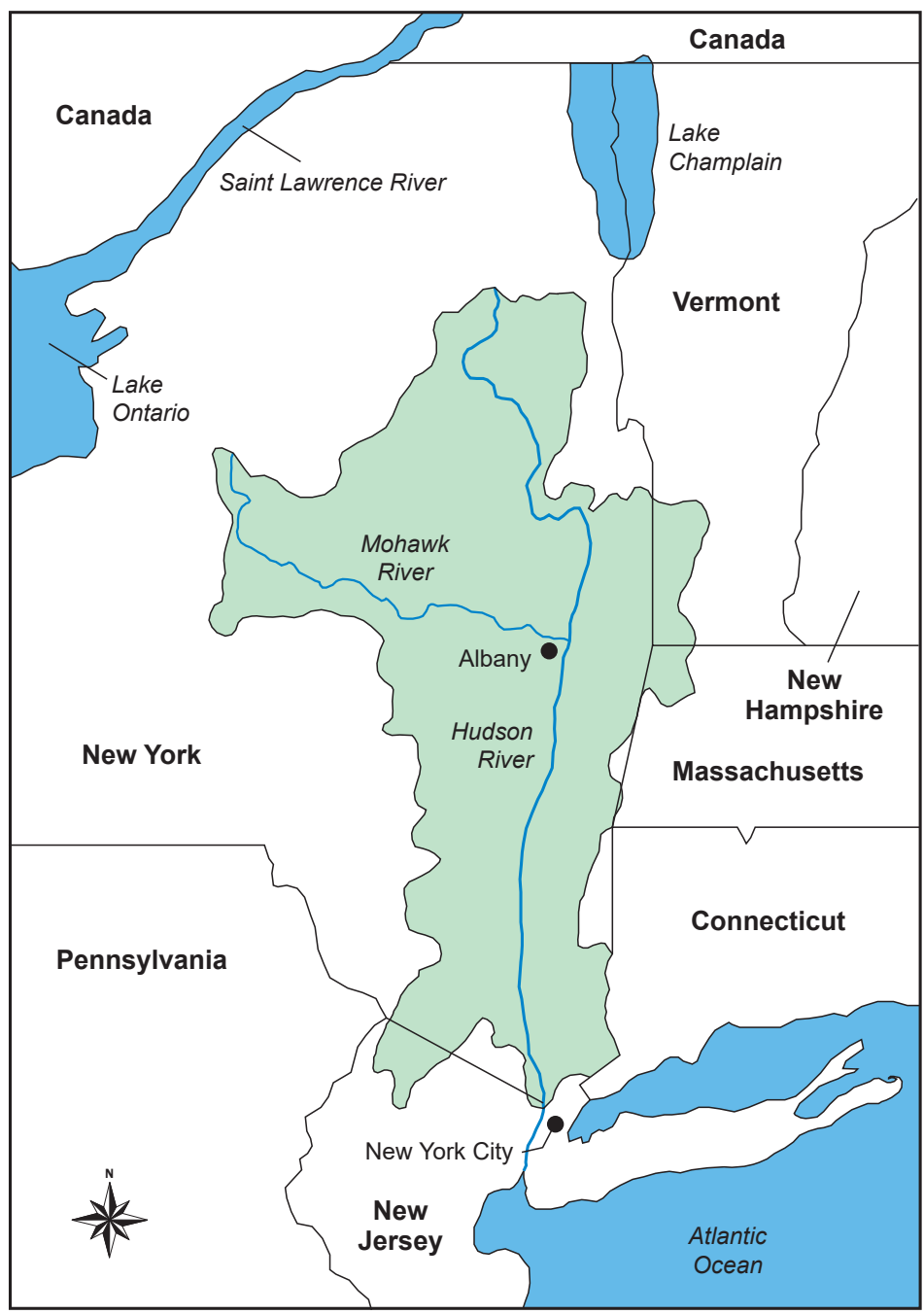

Legend
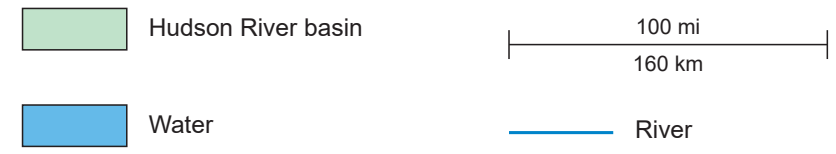

1890, the US Army Corps of Engineers improved river navigation with dikes to narrow and deepen the river for larger boats to transport raw and finished products. The deepened channel eliminated shallow waters and the habitat that native river plants and animals needed to survive and thrive (Rothstein 2019). The river ecosystem was further compromised as industries along the Hudson released byproducts of their processes-oil, solvents, cleaning fluids, heavy metals, and paints into the river (Milman 2019). Following World War II, the river's coastline included factories producing synthetic chemical compounds for electrical components and 
consumer products that became central to the modern economies of the world. One of these compounds was a synthetic chlorinated hydrocarbon called polychlorinated biphenyls (PCB). PCBs were commercially produced from 1929 to 1977 when they were banned by the USEPA. PCBs unintentionally entered the food chain of rivers and have persisted throughout the environment despite extensive dredging and continued monitoring (IDPH 2009).

By the 1960s, the health and safety issues connected with industrial pollution became too large to ignore. The Hudson River was polluted with sewage, heavy metals, butcher waste, and industrial chemicals (Milman 2019). Swimming in the river was a risky action; eating the fish catch was even riskier (Pinkney et al. 2017). The glaring evidence of human disregard and negligence to the conditions of US waters generated an outcry from local citizens and media across the United States. Environmental activists protested smog and poor air quality, water contamination, and careless disposal of hazardous wastes from American industries ( $\mathrm{Hu}$ and Morton 2011). The creation of the USEPA in 1970 and the Clean Water Act in 1972 were just the beginning of efforts to address industrial air and water pollution via monitoring, regulation, and enforcement. In 1980, the USEPA Comprehensive Environmental Response, Compensation, and Liability Act (also known as "Superfund") was authorized by Congress to clean up abandoned hazardous waste sites that contaminate the environment and are a threat to human health (USEPA 2019a). Under the oversight of USEPA, billions of industry and government dollars are spent to clean up waste sites and rivers like the Hudson. In this article, the geology of the Hudson River, early settlement, and industrial growth are discussed with a focus on PCBs and the cleanup investments to initiate the recovery of a valuable water resource.

\section{GEOGRAPHY AND GEOLOGY OF THE HUDSON RIVER}

The headwaters of the $507 \mathrm{~km}(315$ mi) Hudson River emerge from the Appalachian Mountains of Upstate New York and flow from north to south where they are joined by a major tributary, the Mohawk River at Troy, New York (figure 2), to form the Mohawk-Hudson River basin in eastern New York State (figure 1). Near the end of the Wisconsin glaciation, the large glacial lake called Lake Iroquois (encompassing present-day Lake Ontario) drained toward the Mohawk Valley and then south through the lower Hudson River (Morton and Olson 2019).

As the modern-day Hudson River flows south, the mountains of the Catskill Escarpment, a forested ecosystem with $1,000 \mathrm{~m}(3,500 \mathrm{ft})$ peaks, rise high above the Hudson Valley on the west. East of the river are the Taconic Mountains that form the boundaries of eastern New York State and western Massachusetts and Connecticut. South of the Catskill Mountains on the Hudson is the city of Newburgh, located in a valley comprised of lower Silurian or Cambrian slate and limestone. Below Newburgh, the Hudson Highlands tower over both sides of the river as high as $549 \mathrm{~m}(1,800 \mathrm{ft})$ where the river has cut a $32 \mathrm{~km}$ (20 mi) long gorge between Fishkill and Peekskill. Continuing southward, the Hudson flows into the upper and lower New York Bay and the Atlantic Ocean south of NYC.
Here the tidal river becomes an estuary (figure 3) formed during North American glaciation, 26,000 to 13,300 years ago. This deep, fiord-like trait cut from glaciation enables the bays and lower Hudson River to accommodate ocean vessels.

The lower Hudson Valley was filled by a glacier that carried great quantities of glacial till, and as it melted, it left behind what is now known as Long Island and Staten Island. The lower Hudson River cuts through Triassic sandstones and outcroppings of Precambrian gneiss that are not easily eroded. In 1890, James Macfarlane published the American Geological Railway Guide, which beautifully elaborates the geology of the Palisades, a high mountain ridge 122 to $183 \mathrm{~m}$ (400 to $600 \mathrm{ft}$ ) along the western edge of the river with the highest point in the range opposite Sing Sing, $244 \mathrm{~m}(800 \mathrm{ft})$ above the river. His comments echo the Hudson River School of landscape artists:

Viewed from the railroad or from a steamboat on the river, this lofty mural precipice with its huge we a the red masses of upright columns of bare rock, presenting a long, straight unbroken ridge overlooking the beautiful

\section{Figure 2}

The confluence of the Hudson River (background) and the Mohawk River (far right), and the Erie Canal (front and center) near Troy, New York.

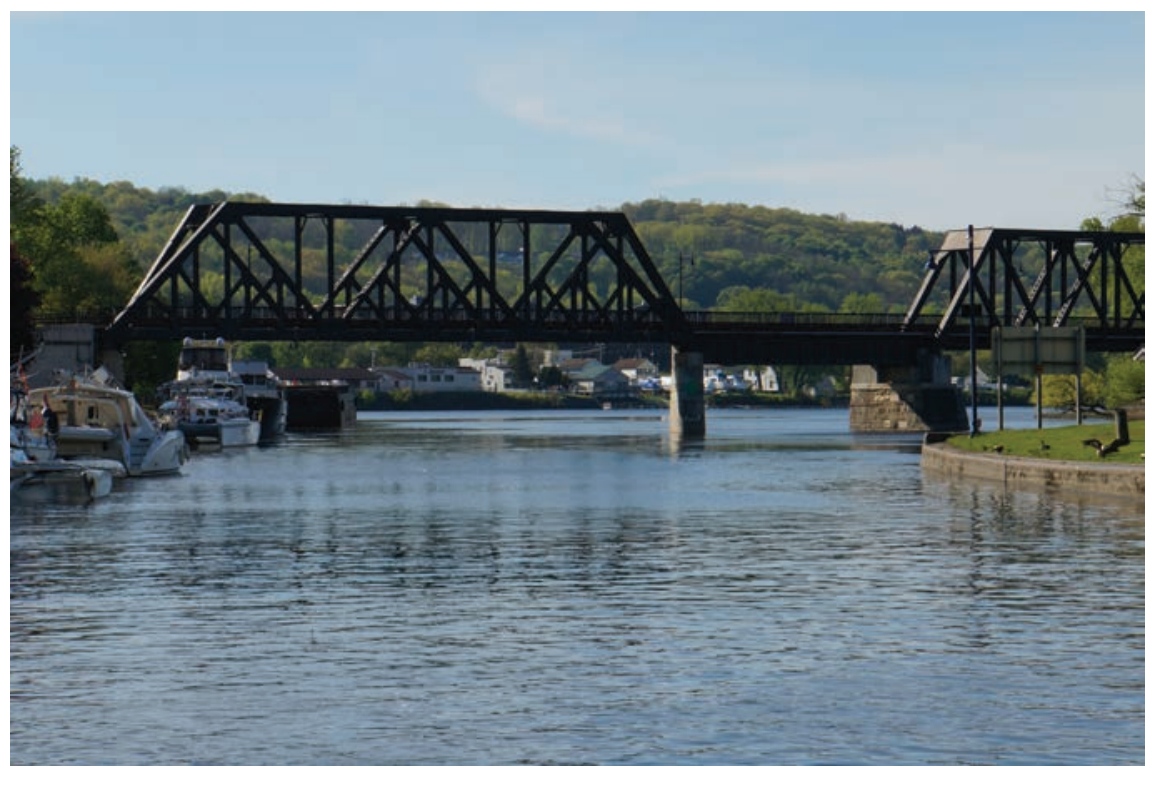




\section{Figure 3}

The lower Hudson River drains into the upper New York Bay and through the Narrows between Staten Island and Long Island into the Atlantic Ocean.

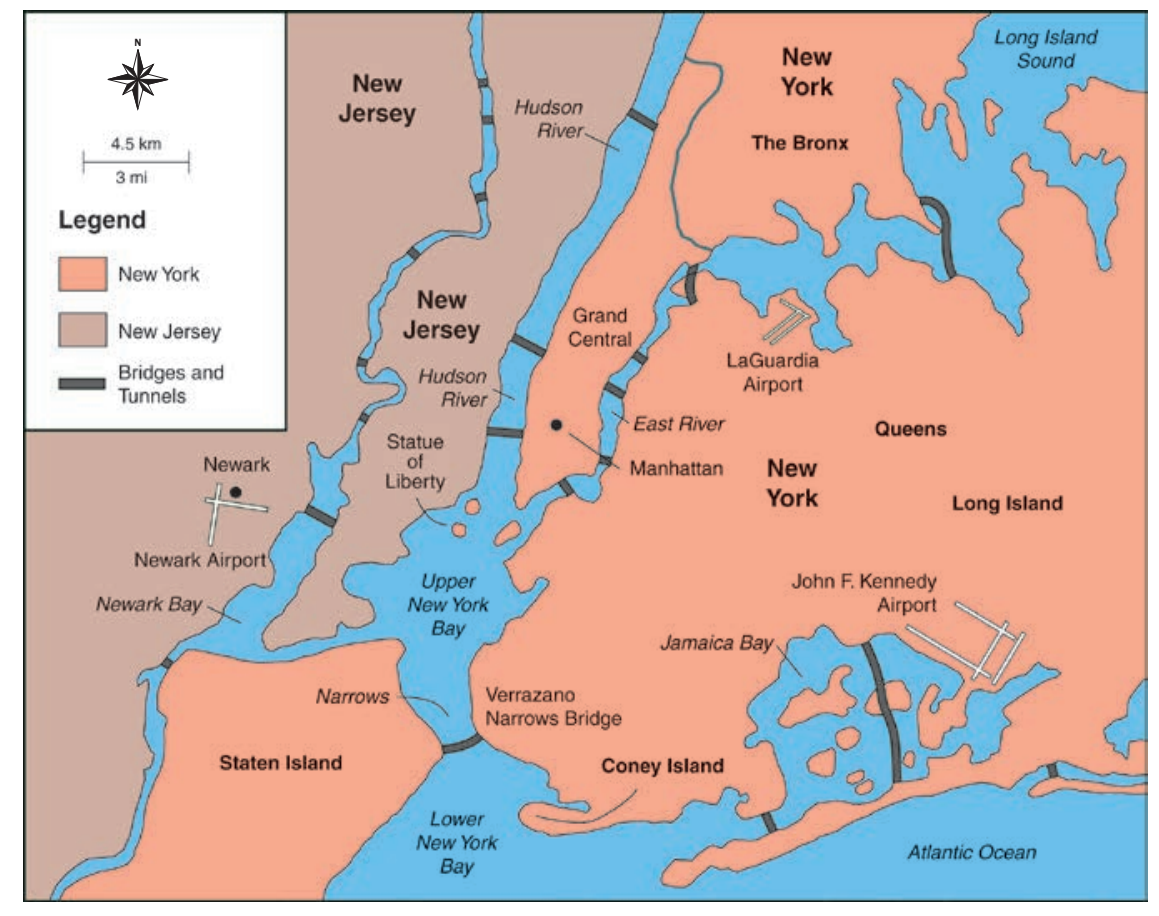

Hudson River, is certainty extremely picturesque. Thousands of travelers gaze at it daily without knowing what it is. This entire ridge consists of no other rock than trap traversing the Triassic formation in a huge vertical dike... The materials of this mountain have undoubtedly burst through a great vent or fissure in the strata, overflowing while in a melted or plastic condition the red sandstone, not with the violence of a volcano, for the adjoining stratus are but little disturbed in position, ... but forced up very slowly and gradually and probably under pressure...

The rock is columnar basalt, sometimes called greenstone, and is solid, not stratified like water-formed rocks, but cracked in cooling and of a crystalline structure...On the east side of this river the formations belong to the first or oldest series of Primary or Crystalline rock, while on the west side they are all Triassic... (Macfarlane 1890)

The rising Atlantic Ocean levels after the Wisconsin glaciation resulted in a marine incursion that buried the coastal plain and resulted in salt water flowing north into the Hudson River as far as the upper New York Bay (figure 3). The Hudson Canyon, a deeply eroded old river bed extends beyond the current shoreline. When Staten Island and Long Island were connected, the Hudson River drained west into New Jersey, through the current Kill Van Kull into Newark Bay, and then south into the current Arthur Kill between the Watchung Mountains and Staten Island into Raritan Bay and the Atlantic Ocean. The Narrows were formed 6,000 years ago at end of the glacial period when the Hudson River breached the terminal moraine and separated Staten Island from Long Island (figure 3). Thus, the present course of the Hudson drains into the lower New York Bay between Staten Island and Long Island and into the Atlantic Ocean.

\section{NATIVE AMERICANS IN THE LOWER HUDSON VALLEY}

The lower Hudson Valley was the territory of the Acquackaronk and Hackensack Indians, members of the Lenape tribes. These Native Americans were primarily fishers and built weirs (overflow dams) on the Hudson and tributary rivers to create pools to trap fish (Levine 2016). The Lenape spoke the dialect known as Munsee and were known as Munsee Indians (Levine 2016). The Munsee Indians greeted the French explorer Glovanni da Verrazano who discovered the Narrows in 1524 and later interacted with explorer Henry Hudson who traveled the Hudson River north in 1609 in search of a northwest passage to the Pacific Ocean.

The Munsee Indians grew beans, corn (Zea mays), and squash, and gathered nuts, hickory (Carya), butternuts (Juglans cinerea), walnuts (Juglans), chestnuts (Castenea), acorns (Quercus), and berries. They hunted and ate elk (Cervs elapus), bear (Ursidae), rabbits (Oryctolagus cuniculus), whitetailed deer (Odocoileus virginianus), turkey (Meleagris gallopavo), squirrels (Sciuridae), and river otters (Lontra canadensis) (Levine 2016). They fished the Hudson River for sturgeon (Acipenser oxyrinshus oxyrinchus), shad, herring, and striped bass (Morone saxatilis), which were smoked, dried, or roasted.

The Atlantic sturgeon was an abundant fish in the Hudson River and excellent source of protein for the Indians. Sturgeon hatch in freshwater coastal rivers like the Hudson and head out to sea as juveniles, reaching $5 \mathrm{~m}$ (16 ft) and up to $363 \mathrm{~kg}$ $(800 \mathrm{lb})$ at maturity. They return to the river of their birthplace to spawn and lay eggs at adulthood (NOAA Fisheries 2019). Northern adults spawn during late summer and fall, with females exiting the river for the ocean four to six weeks after spawning, and males remaining in the river or lower estuary until fall (NOAA Fisheries 2019). Sturgeon are bottom feeders eating crustaceans, worms, and mollusks. After hatching, the larvae hide in sediments and drift downstream until they reach brackish waters where they grow toward adulthood and then swim into coastal waters (NOAA Fisheries 2019).

This unique fish has bony plates (scutes) that run along its body, a shark-like tail, and a snout with barbells in front of its mouth. In the late 1800s, Atlantic sturgeon eggs, known as black gold, produced a high quality caviar that was in high demand in the colonies and for export. National Oceanic and Atmospheric Administration Fisheries (2019) reports almost 3,175 t 
$\left(7 \times 10^{6} \mathrm{lb}\right)$ of sturgeon caught in 1887 , with a significant decline in the catch to $9 \mathrm{t}(20,000 \mathrm{lb})$ by 1905 and less than $0.2 \mathrm{t}$ $(400 \mathrm{lb})$ by 1989 . Once plentiful, this slow growing fish today is an endangered species. Population declines are attributed to habitat degradation, such as chemical contamination of river sediments in rearing areas and dredging as well as entanglement in fishing gear.

\section{SETTLEMENT OF THE HUDSON RIVER VALLEY}

The Hudson Estuary was a natural harbor for ocean vessels and their passengers: explorers, traders and settlers coming to the New World. Like the Lenape Indian tribes, the newcomers used the Hudson River as a navigation route between the ocean and interior lands. In the 1600s, the Dutch began to colonize the Hudson Valley and built Fort Orange (presentday Albany, New York) on the west bank of the Hudson River in 1624 as a trading post. The Dutch established two other fur-trading posts, one at New Amsterdam on the southern tip of Manhattan Island and Wiltwyck (present-day Kingston) on the Hudson River about halfway between Fort Orange and New Amsterdam. The British navy invaded the colony of New Netherlands and its capital city, New Amsterdam, in 1664, and the Dutch surrendered the defenseless city of traders. New Amsterdam was renamed New York (NYC) in honor of the Duke of York who sponsored the expedition.

The lower Hudson Valley became an agricultural hub under the British colonial rule. During the Revolutionary War, the Hudson River became a major battle field as the British controlled the river north and its tributaries as well as Lake Champlain waterways, giving them control from Montreal, Canada, to NYC. As the new nation won its independence and pushed westward, NYC grew in population and commerce. The construction of the New York Canal System (1817 to 1880) accelerated the US Industrial Revolution and spread new ideas, inventions, and prosperity throughout New York State. The canal system was built on the backbone of the Hudson and Mohawk rivers, connecting NYC harbor to the capital at Albany and to points west to Lake Ontario and north to Lake Champlain and the St Lawrence Seaway (Morton and Olson 2019). This made the Hudson River, with its abundance of water, nearby forests for fuel, and a waterway that easily and inexpensively transported raw and finished products and labor, an ideal place to locate factories and new enterprises.

\section{NEW INDUSTRIAL PRODUCTS: POLYCHLORINATED BIPHENYLS}

A few short decades after Thomas Edison lit up a public street with the incandescent light bulb (1879), the concept of electricity was transformed from a novel scientific experiment to an essential infrastructure needed for everyday living. Factories, office buildings, and homes demanded electricity. Innovations and markets for new consumer appliances using electricity, like the electric refrigerator (invented in 1913), grew quickly. Cities and their industries invested heavily in the infrastructure necessary to ensure reliable and abundant supplies of electricity that underlie today's economic prosperity. The 1964 to 1965 New York World's Fair showcased the entrepreneurial spirit and success of American manufacturing, mass production, and Dupont's "Wonderful World of Chemistry." Innovations produced an amazing array of consumer products, electrical gadgets, futuristic car designs, nascent computer technologies, and expanded capacities to apply chemistry. The New York Power Authority (NYPA), the largest state public power organization in the United States, with more than 2,253 circuit $\mathrm{km}(1,400$ circuit mi) of transmission lines and 16 generation facilities, featured an $8 \mathrm{~m}(26 \mathrm{ft})$ scale reproduction of the NYPA St. Lawrence hydroelectric plant.

New York State and Hudson River industries were on the leading edge of research and development of products from synthetic chemicals. Between 1929 and 1977, PCB synthetic compounds were used in the production of lubricants, hydraulic fluids, plasticizers, capacitors and transformers, paints, inks, flame retardants, and adhesives (Faroon et al. 2003; IDPH 2009; Green Facts 2006). Two General Electric (GE) capacitor manufacturing plants were built at Fort Edward and
Hudson Falls, New York, on the Hudson River north of Albany and used PCBs from 1947 to 1977 in their production processes.

Capacitors and transformers are basic components of electric circuits. The electric circuit enables electric charges to flow along a closed path. The capacitor is connected to a voltage supply and can store electrical charge making it available on demand. The rate at which electric energy is transferred by an electric circuit is called electric power. The transformer enables electrical power to be transmitted more efficiently at higher voltage but lower current. Dielectric fluids prevent electric discharges, thus acting as insulators in high voltage equipment. The properties of PCBs are especially well-suited for use in the dielectric fluids of capacitors and transformers. These properties include taking the form of either an oily liquid or a clear to yellow solid with no smell or taste. PCBs are relatively stable chemical mixtures resistant to acids and alkalis and extreme temperatures and pressures (IDPH 2009; Faroon et al. 2003). PCBs have a similar basic chemical structure of carbon $(\mathrm{C})$, hydrogen $(\mathrm{H})$, and chlorine (Cl) atoms that can be combined to form 209 different PCB molecules (Green Facts 2009) (figure 4). Some of these forms are more harmful than others and persist in the environment, often depending on the degree of chlorination (number of $\mathrm{Cl}$ atoms) and the structural uniformity of the chlorination pattern (Farron et al. 2003).

The release of PCBs in the environment can happen through manufacturing spills, improper disposal and storage, leaks from electrical equipment, and landfills of obsolete products containing PCBs. Environmental contamination can occur through volatilization and/or adsorption to soil and sediments. When adsorbed to soils and sediments, the half-life can run from months to years. The strength of attachment to soils and sediments increases with the extent to which $\mathrm{H}$ atoms on the biphenyl molecule are replaced with $\mathrm{Cl}$ (Faroon et al. 2003). In PCBs, chlorine atoms $\left(\mathrm{Cl}_{n} \mathrm{H}_{(10-n)}\right)$ can replace some or all of the $\mathrm{H}$ atoms on a biphenyl molecule (figure 4). At very high temperatures, PCB compounds are combustible, creating highly hazardous by-products. The pyroly- 


\section{Figure 4}

Biphenyl molecule with the numbering system. In polychlorinated biphenyls (PCBs) some or all of the 10 hydrogens (attached to carbon atoms numbers 2 to 6 and 2' to 6') are substituted with chlorines, thereby creating groups of chlorinated compounds (congeners) (Faroon et al. 2003).

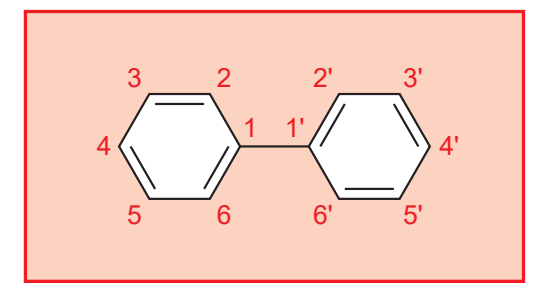

sis of PCB mixtures with chlorobenzenes can produce polychlorinated dibenzodioxins (Faroon et al. 2003).

\section{IMPACTS OF HUDSON RIVER POLYCHLORINATED BIPHENYLS}

PCBs are a persistent organic pollutant found in air, water, soils, and sediments throughout the US environment and globally (IDPH 2009; Madden and Skinner 2016). They adhere strongly to soils and sediments, and water can transport them long distances. When ingested by humans, animals, fish, and aquatic animals, PCBs accumulate in fatty tissues and eggs (Madden and Skinner 2016) and become biomagnified (concentrated) as they travel up the food chain. Fish, water fowl, and aquatic animals usually contain higher PCB concentrations than the aquatic plants and invertebrates they feed on (Madden and Skinner 2016). For example, 2008 research by Madden and Skinner (2016) explain high PCB concentrations in newly hatched mallard ducks (Anas platyrhynchos) downstream of the GE plant sites as the result of ducks feeding on organisms from the river and ingestion of contaminated river sediments.

Most people are exposed to PCBs when they eat fish, milk products, and aquatic animals. Direct contact with PCBs does not automatically create a health problem. Health impacts occur from a combination of (1) length of time a person is exposed, (2) the amount of PCBs that enter and concentrate in the body (they are not easily eliminated); and (3) body sensitivity to PCBs (IDPH 2009). Visible effects of PCB toxicity are evidenced by yellow skin lesions, a condition called chloracne, and short-term changes in liver function. PCBs are neurotoxins-meaning they affect the nervous system and the brain as well as reproductive and endocrine systems (USEPA 2015). Development of lesions, adverse effects on survival, and reduced reproductive capacity have been associated with PCB exposure in fish (Pinkney et al. 2017). Human studies find PCBs probable carcinogens with increased risk of digestive system, liver, and skin cancers. There are also concerns that high concentrations of PCBs may have neurological health effects, lead to reduced fertility, and be a cause of low birth weights.

GE manufacturing plants at Fort Edwards and Hudson Falls released into the Hudson River over 590,000 kg (1.3 × $10^{6} \mathrm{lb}$ ) of PCBs from 1940 through 1977 when USEPA banned the production of PCBs (Pinkney et al.2017). Sediments and biota were contaminated the entire length of the Hudson River from Fort Edward south to NYC (Madden and Skinner 2016). More than two-thirds of the PCBs in sediments deposited between early

\section{Figure 5}

Recreational fishing boats on the lower Hudson south of the Troy Federal Dam. A fish advisory remains in effect with cautions against eating them.

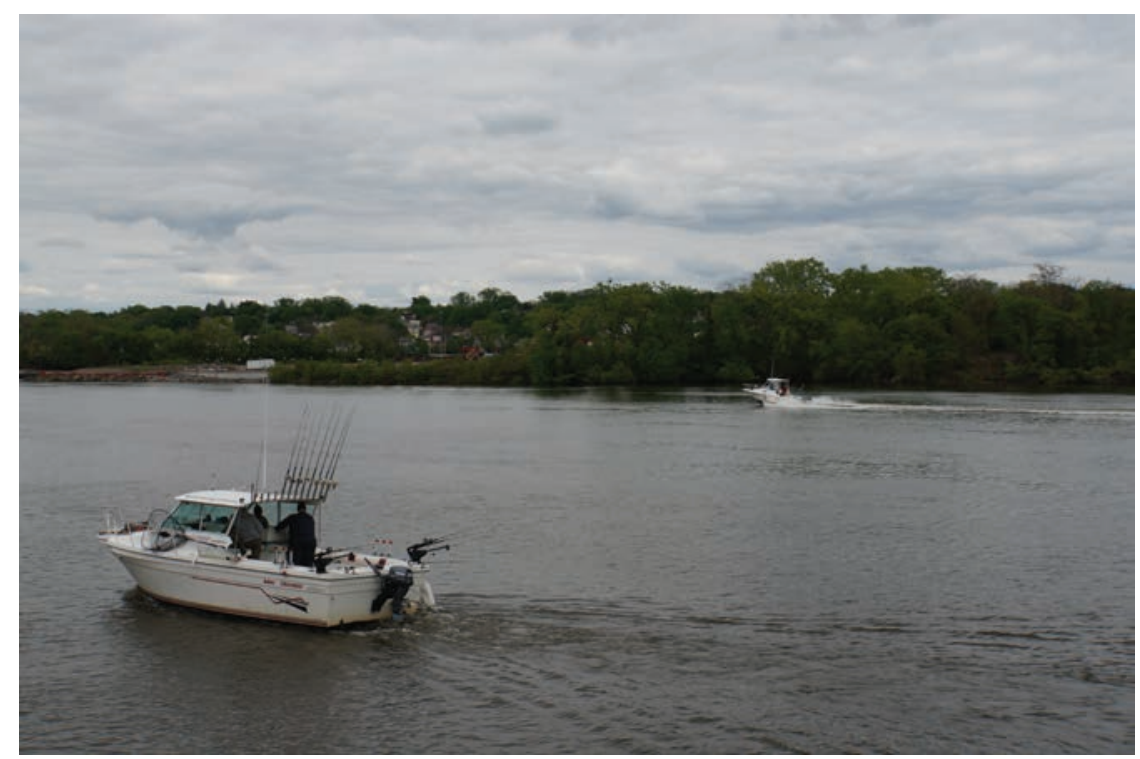

1970 and 1989 in NYC Harbor traveled almost $300 \mathrm{~km}$ (186 mi) downstream from the two upstream GE capacitor manufacturing plants (Pinkney et al. 2017; Madden and Skinner 2016). Recreational fishing (figure 5) of the Hudson was banned from 1976 to 1995 , and a fish consumption advisory continues in effect in the contaminated reach. Over $90 \%$ of ducks tested in 2008 downstream of the GE plants but above the Hudson tidal river influence exceeded the US Food and Drug Administration $3.0 \mathrm{mg} \mathrm{m}^{-1}$ tolerance level for PCBs in fatty tissues (Madden and Skinner 2016). In 1984, the USEPA designated $322 \mathrm{~km}$ (200 mi) of the Hudson River a PCB Superfund Site.

\section{HUDSON RIVER CLEANUP TO ADDRESS THE POLYCHLORINATED BIPHENYLS CONTAMINATION}

The Comprehensive Environmental Response, Compensation, and Liability Act of 1980 (amended 1986; Superfund) is charged with addressing top priority hazardous waste sites with high levels of potential threat to public health and the environment (USEPA 1981; 2019a). Funded by industry and federal and state governments, Superfund cleans up 
sites where responsible parties cannot be determined or cannot afford to pay for the cleanup. Although the Hudson River was placed in 1984 on USEPA's National Priorities List of the country's most contaminated hazardous waste sites, it was not until 2002 that USEPA determined that targeted environmental dredging would be necessary (Pinkney et al. 2017). Dredging was begun in 2009 on a $64 \mathrm{~km}$ (40 mi) stretch between Fort Edward and Troy, New York, to remove an estimated $2.03 \times 10^{6} \mathrm{~m}^{3}\left(2.65 \times 10^{6} \mathrm{yd}^{3}\right)$ of PCBcontaminated sediments (USEPA 2015). GE's financial contribution to the cleanup project was reported April of 2019 to exceed US $\$ 1.7$ billion (USEPA 2019b).

Prior to the dredging decision, the federal government and New York State monitored and evaluated the water quality, sediment, air quality, fish, and wildlife of the lower Hudson River from the Federal Dam at Troy to the southern tip of Manhattan at the Battery in NYC to determine if the river was cleaning itself. This evaluation revealed the river was not able to clean itself, and the PCB contaminated sediment was a serious risk to human health and the environment. The USEPA dredging project consisted of three river sections in the upper Hudson River (upstream from Troy): Section 1 from the former Fort Edward Dam to the Thompson Island Dam; Section 2 from the Thompson Island Dam to the Northumberland Dam; and Section 3 from the Northumberland Dam to the Federal Dam in Troy. To manage the complexity of the project, dredging of the upper Hudson area was partitioned into "certification units" of approximately 2 ha (5 ac).

River sediment dredging (2009 to 2015) occurred after winter ice melt (May) and before the onset of winter weather (November). In the first year, a $9.7 \mathrm{~km}$ (6 mi) stretch of contaminated sediment near Fort Edward was removed ( 216,369 $\left.\mathrm{m}^{3} \quad\left[283,000 \mathrm{yd}^{3}\right]\right)$. Additional evaluation in 2010 by an independent scientific panel of scientists and stakeholders guided USEPA in planning for the next phase of the cleanup (Stainbrook 2005). The second phase (June 2011 to 2015) removed $\sim 1.9 \times 10^{6} \mathrm{~m}^{3}\left(2.5 \times 10^{6} \mathrm{yd}^{3}\right)$ of PCBcontaminated river sediment for a total $\sim 2.1 \times 10^{6} \mathrm{~m}^{3}\left(2.75 \times 10^{6} \mathrm{yd}^{3}\right)$ of sediment dredged and processed for disposal.

In April of 2019 USEPA reported continuing efforts to evaluate human and ecological risks and mitigation options of PCB sediment contamination in the 69 $\mathrm{km}$ (43 mi) floodplain from Hudson Falls to Troy. This included $\sim 8,000$ soil samples collected from over 500 floodplain properties. Where elevated PCB concentrations are found, signage and temporary soil cover with turf grasses will be planted until floodplain cleanup plans can be finalized (USEPA 2019b).

\section{AN URBANIZED WATERWAY}

The Hudson River is an urbanized waterway that received $\mathrm{PCB}$ from many sources over a long period of time (Rodenburg and Ralston 2017). USEPA from 1999 to 2003 measured PCB sediment deposits in the NYC/New Jersey Harbor to estimate PCB loads in the harbor prior to dredging the upper Hudson River. These dated sediment cores enabled them to identify sources of contamination and timelines of sediment deposition. Findings showed that GE capacitor plants above the Federal Dam at Troy contributed almost half of the total PCB Harbor load (Rodenburg and Ralston 2017). They also revealed the following timeline: (1) during the 1970s, $75 \%$ of $\mathrm{PCBs}$ in the harbor were from the upper Hudson River; (2) between 1970 and 2000 about $30 \%$ to $50 \%$ of PCBs in the lower Hudson River were distributed throughout the harbor; (3) in the 1980s, when local PCB manufacturing peaked, $\mathrm{PCB}$ harbor sediment cores revealed almost equal sediment deposits from the upper Hudson River and local sources; and (4) from 1970 to 2000, local PCB sources declined, thereby increasing the concentration of PCBs from the upper Hudson River.

PCBs were a component of many products made by several companies for almost 50 years. The oldest PCBs found in the deepest sediment core in NYC/ New Jersey Harbor are thought to have occurred unintentionally with the inadvertent production of PCBs during the manufacture of titanium dioxide and in foundry wax processes, perhaps associated with color organic pigments (Rodenburg and Ralston 2017). The NYC/New Jersey Harbor 1999 to 2003 sediment cores show a historical legacy of PCB contamination from a variety of sources: wastewater, storm water, and combined sewer overflows as well as redistributions from the upper Hudson River. With the completion of upper Hudson dredging in 2015 and the subsequent five-year review, USEPA is monitoring fish, water, and sediments of the lower Hudson River to determine possible cleanup action (USEPA 2019b)

\section{AN “ENORMOUS” ATLANTIC STURGEON IN THE HUDSON RIVER}

The Hudson River story of exploration, settlement, despoilment, reclamation, and recovery could be the history of other rivers throughout the United States and the world. Economic progress has not coexisted well with wise protection of soil and water resources. New York State has made huge efforts to address the complex and difficult issues of managing their river landscapes while ensuring economic and environmental well-being (Morton and Olson 2019). Recognizing the need for river and land use planning along the Hudson River, the New York State Department of Environmental Conservation and Cornell University's Department of Natural Resources in 2001 implemented a Hudson River Conservation, Estuary, and Land Use Program. The intent is to provide communities with tools, training, and technical support to better balance protection and conservation of at-risk natural resources with present and future economic growth.

The Guardian, a British daily newspaper headlined in March of 2019 "startling evidence" of the Hudson River's recovery from "decades as New York's sewer" (Milman 2019). University of Delaware geologist, John Madsen reported sonar images of an "enormous" $4.3 \mathrm{~m}$ (14 ft) Atlantic sturgeon about 70 miles north of NYC. This 80-year-old female is part of a very small population of sturgeons known to spawn near Hyde Park. While their populations have not rebounded from the early days of colonial settlement, this is an encouraging sign that the river ecosystem can be returned to better health. However, a fish advisory remains in effect with cau- 
tions against eating. USEPA fish tissue testing post upper Hudson dredging also remains inconclusive.

Recovery of the Hudson River has been a long and complex process that is not yet fully realized. It will require continued vigilant local environmental advocacy and strong state and national government partnerships. The Clean Water Act and the Superfund legislation that authorized USEPA has played a critical role in the success of PCB contamination removal and persistent investments to restore the Hudson River. The built environment-commercial and residential buildings - that extends beyond the Hudson River shores and the burgeoning NYC population have obscured the natural flow of the Hudson River and its visibility to daily life. The challenge will be to keep the vision of a clean river visible. The Hudson serves cultural, aesthetic, recreational, functional, economic, and commercial needs. The struggle to meet these complex, multifunctional roles will be ongoing. The coexistence of humans and nature will need constant vigilance to produce a landscape worthy of the next generation of landscape painters.

\section{ACKNOWLEDGEMENTS}

Published with funding support from USDA National Institute of Food and Agriculture, Water Division; the Iowa Agriculture and Home Economics Experiment Station, College of Agriculture and Life Sciences at Iowa State University, Ames, Iowa; and the Director of the Illinois Office of Research, College of Agricultural, Consumer, and Environmental Science, University of Illinois, Urbana, Illinois.

\section{REFERENCES}

Faroon, O.M., L.S Keith, C. Smith-Simon, and D.T. DeRosa. 2003. Polychlorinated biophenyls: Human health aspects. Agency for Toxic Substances and Disease Registry, Atlanta, Georgia. Concise International Chemical Assessment Document 55. Geneva:World Health Organization. http://www.inchem.org/documents/cicads/cicads/cicad55.htm\#1.0.

Green Facts. 2006. PCBS Polychlorinated biophenyls. Facts on Health and the Environment. Brussels: Cogeneris sprl. https://www.greenfacts. org/en/pcbs/.

Hu, Z., and L.W. Morton. 2011. Region water quality concern and environmental attitudes. In Pathways for Getting to Better Water Quality, eds. L.W. Morton and S.S. Brown. New York: Springer.

IDPH (Illinois Department of Public Health). 2009. Polychlorinated Biphenyls (PCBs) Environmental Health Fact Sheet. Springfield, IL: Division of Environmental Health.

Levine, D. 2016. Hudson Valley's Tribal History. Hudson Valley Magazine, June 24, 2016. http://www.hvmag.com/ Hudson-Valley-Magazine/July-2016/ The-Native-People-of-the-Hudson-Valley.

Macfarlane, J. 1890. American Geological Railway Guide. New York: D. Appleton and Company. https://accessgenealogy.com/new-york/geology-hudson.htm.

Madden, S.S., and L.C. Skinner. 2016. Polychlorinated biphenyls (PCBs) in adult and juvenile mallards (Anas platyrhynchos) from the Hudson River, New York, USA. Environmental Pollution 216:487-499.

Milman, O. 2019. Hudson River shows signs of rebound after decades as New York's sewer. The Guardian. March 28, 2019.

Morton, L.W., and K.R. Olson. 2019. Corridor of migration, navigation and innovation: The New York State Canal System. Journal of Soil and Water Conservation 74(5):102A-108A, doi:10.2489/jswc.74.5.102A.

NOAA (National Oceanic and Atmospheric Administration) Fisheries. Atlantic Sturgeon. Silver Spring, MD: National Oceanic and Atmospheric Administration Fisheries. https://www.fisheries.noaa.gov/species/ atlantic-sturgeon.

Pinkney, A.E., M.S. Myers, and M.A. Rutter. 2017. Histophathology of brown bullhead (Ameiurus nebulosus), smallmouth bass (Micropterus dolomieu) and yellow perch (Perca flavescens) in relation to the polychlorinated biphenyl (PCB) contamination in the Hudson River. Science of the Total Environment 575:1325-1338.

Rodenburg, L.A., and D.K. Ralston. 2017. Historical sources of polychlorinated biphenyls to the sediment of the New York/New Jersey Harbor. Chemosphere 169:450-459.

Rothstein, E. 2019. Reflections on a river. The Wall Street Journal, July 9, 2019.

Stainbrook, K. 2005.Anticipating Changing the Hudson River Watershed: An Economic and Ecological Risk Assessment: Applications to Watershed Management. Boca Raton, FL: CRC Press.

USEPA (United States Environmental Protection Agency). 1981. EPA announces first 114 toppriority Superfund sites. USEPA Archives. Washington, DC: US Environmental Protection
Agency. https://archive.epa.gov/epa/aboutepa/ epa-announces-first-114-top-priority-superfund-sites.html.

USEPA. 2015. Sixth season of Hudson River dredging begins, historic dredging project draws to a close, next up: clean up floodplains. USEPA Archives. Washington, DC: US Environmental Protection Agency. https://archive.epa.gov/epa/newsreleases/ sixth-season-hudson-river-dredging-begins-historic-dredging-project-draws-close-next.html.

USEPA. 2019a. Summary of the Comprehensive Environmental Response, Compensation, and Liability Act (Superfund) 42 US Code 9601 et seq. (1980). https://www.epa.gov/laws-regulations/ summary-comprehensive-environmental-responsecompensation-and-liability-act.

USEPA. 2019b. After extensive consultation and analysis, EPA announces two actions on the Upper Hudson River PCB cleanup in New York. Albany, NY: US Environmental Protection Agency. https://www.epa.gov/sites/ production/files/2019-04/documents/hudson_ news_release_final_0.pdf. 